\title{
Pengaruh perbedaan level pupuk urin terfermentasi pada media tanam hidroponik terhadap komposisi dan kecernaan nutrien fodder sorgum
}

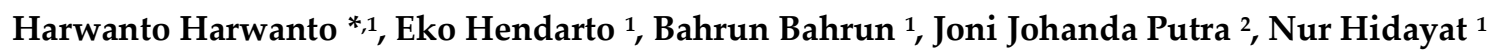 \\ ${ }^{1}$ Fakultas Peternakan, Universitas Jenderal Soedirman, Purwokerto, 53122 \\ 2Fakultas Perikanan dan Ilmu Kelautan, Universitas Jenderal Soedirman, Purwokerto, 53122 \\ *Correspondence: harwanto.fapet@unsoed.ac.id
}

Received: November 29 $9^{\text {th }}, 2020$; Accepted: September 10 ${ }^{\text {th }}, 2021$; Published online: November 17th 2021

\section{Abstrak}

Tujuan: Penelitian bertujuan untuk mengetahui komposisi nutrien dan kecernaan secara in vitro fodder sorgum (Sorghum bicolor (L.) Moench) dari pengaruh penambahan pupuk urin terfermentasi pada media tanam hidroponik.

Metode: Penelitian menggunakan tanaman sorgum dari varietas numbu yang ditanam secara hidroponik pada fase fodder, yang dilaksanakan pada bulan Juni - September 2020. Perlakuan penelitian berupa media air (T1), urin terfermentasi $12,5 \mathrm{~mL} / \mathrm{L}$ (T2) dan $25 \mathrm{~mL} / \mathrm{L}$ media air (T3) dengan 4 ulangan. Pupuk urin yang digunakan berasal dari urin Sapi Peranakan Ongole yang difermentasi selama 21 hari. Fodder sorgum ditanam selama 15 hari. Hasil pemanenan fodder dilanjutkan analisis proksimat dan kecernaan nutrien secara in vitro. Paramater pengamatan meliputi komposisi nutrien berupa bahan kering (BK), bahan organik (BO), protein kasar (PK), lemak kasar (LK), serat kasar (SK), total digestible nutrient (TDN) serta kecernaan bahan kering dan kecernaan bahan organik (KcBO). Analisis data menggunakan rancangan acak lengkap pola searah dan dilanjutkan uji Duncan's Multiple Range Test untuk mengetahui signifikansi.

Hasil: Hasil penelitian menunjukkan penambahan urin terfermentasi tidak berpengaruh pada $\mathrm{BK}, \mathrm{BO}$, dan $\mathrm{LK}$, namun berpengaruh nyata $(\mathrm{P}<0,05)$ terhadap $\mathrm{PK}, \mathrm{SK}, \mathrm{TDN}$ serta kecernaan nutrien. Perlakuan T2 dan T3 meningkatan PK sebesar 6,31\% dan 11,23\% dibandingkan T1. Perlakuan T3 meningkatkan KcBO sebesar 3,06\% dibandingkan T1.

Kesimpulan: Penambahan pupuk urin terfermentasi pada media tanam hidroponik sebanyak 25,0 $\mathrm{mL} / \mathrm{L}$ mampu meningkatkan komposisi protein kasar dan kecernaan bahan organik fodder sorgum pada umur panen 15 hari.

Kata Kunci: fodder sorgum; kecernaan nutrien in vitro; komposisi nutrien; urin terfermentasi

\section{Abstract}

Objective: This study aims to determine the nutritional value and nutrient digestibility by in vitro of fodder sorghum (Sorghum bicolor (L.) Moench) from the effect of the addition of fermented urine fertilizer to the hydroponic media.

Methods: The research used sorghum Numbu varieties grown hydroponically in the fodder phase, which was carried out in June - September 2020. The research treatments consist of water medium (T1), fermented urine $12.5 \mathrm{~mL} / \mathrm{L}$ (T2) and $25 \mathrm{~mL} / \mathrm{L}$ media (T3) with 4 replications. The urine fertilizer 
used was derived from fermented Ongole Crossbreed cow urine for 21 days. Fodder sorghum planted for 15 days. The results of the fodder harvest were analyzed by proximate and in vitro nutrient digestibility. Observation nutritional value parameters consists of dry matter (DM), organic matter $(\mathrm{OM})$, crude protein $(\mathrm{CP})$, ether extract (EE), crude fiber $(\mathrm{CF})$, total nutrient digestible (TDN), dry matter digestibility (DMD) and organic matter digestibility (OMD). Data were analyzed using one way ANOVA design, the significance by Duncan's Multiple Range Test.

Results: The results showed that the addition of fermented urine had no effect on the DM, OM, and $\mathrm{EE}$, but had a significant effect $(\mathrm{P}<0.05)$ on $\mathrm{CP}, \mathrm{CF}, \mathrm{TDN}$ and nutrient digestibility. The $\mathrm{T} 2$ and $\mathrm{T} 3$ treatments increased crude protein by $6.31 \%$ and $11.23 \%$ compared to $\mathrm{T} 1$. T3 treatment increased organic matter digestibility by $3.06 \%$ compared to $\mathrm{T} 1$.

Conclusions: It can be concluded that the crude protein and organic matter digestibility of sorghum fodder at 15 days harvest stage, increases with the addition of fermented cattle urine up to $25.0 \mathrm{ml} / \mathrm{L}$ hydroponic media.

Keywords: fermented cattle urine; nutrient digestibility; nutritional value; sorghum fodder

\section{PENDAHULUAN}

Salah satu alternatif penyediaan hijauan pakan ternak berupa pengembangan sistem tanam secara hidroponik. Hidroponik merupakan metode budidaya hijauan yang dapat diaplikasikan untuk mengatasi kendala ketergantungan iklim dan ketersediaan lahan bagi usaha peternakan. Wahyono et al. [1] menyatakan bahwa budidaya tanaman secara hidroponik dapat dilakukan dalam periode yang singkat, hanya menggunakan media cair dan dilakukan di lingkungan yang terkontrol. Sharma et al. [2] menambahkan bahwa hidroponik deep water culture system merupakan salah satu metode hidroponik yang memiliki karakteristik akar tanaman tersuspensi dalam media nutrisi hidroponik sehingga tanaman dapat tumbuh cepat dan menghasilkan biomasa yang besar. Tanaman serealia seperti jagung, gandum, barley, dan sorgum merupakan jenis tanaman yang banyak dibudidayakan sebagai pakan ternak. Sorgum merupakan tanaman yang potensial dikembangkan sebagai green fodder karena berkembang baik di lingkungan tropis [3]. Selain itu tanaman sorgum memiliki keunggulan lebih tahan terhadap kondisi lingkungan yang kering dibandingkan tanaman jagung, efektif terhadap penyerapan air dan unsur hara dalam proses pertumbuhan serta memiliki kemampuan regrowth [4].

Kandungan nutrisi dan kecernaan hijauan pakan hasil budidaya hidroponik dipengaruhi oleh umur pemanenan.
Hasil penelitian [5] hijauan pakan hasil budidaya hidroponik pada tanaman jagung menghasilkan protein kasar yang lebih tinggi dan serat kasar lebih rendah dibandingkan hijauan yang ditanam secara konvensional. Di sisi lain media tanam dan pupuk mempunyai peranan penting dalam pertumbuhan. Unsur hara pada media berperan penting dalam metabolisme tanaman. Koten et al. [6] menyatakan bahwa nitrogen merupakan unsur yang dapat meningkatkan pertumbuhan, produksi dan kualitas hijauan tanaman, pembentukan daun tanaman, sintesis asam amino dan protein dalam tanaman. Tanaman hijauan sorgum memilki kandungan protein $9,90 \%$. Kebutuhan nitrogen pada tanaman pakan seperti sorgum sangat tinggi 10 dan $15 \mathrm{~g} / \mathrm{m}^{2}$ [7] dibandingkan dari kelompok rerumputan. Kondisi ini menyebabkan akumulasi hasil fotosintesis sehingga meningkatkan produktivitas tanaman.

Urin sapi merupakan salah satu limbah peternakan yang mengandung unsur nitrogen yang berpotensi digunakan sebagai pupuk organik pada tanaman. Mudhita et al. [8] menyatakan urin ternak sapi mengandung $\mathrm{C} / \mathrm{N}$ ratio 23,33, phosphor available 0,02 ppm, dan organik matter 1,21\%. Kandungan nitrogen urin diharapkan dapat termanfaatkan oleh tanaman sebagai sumber $\mathrm{N}$ untuk proses pertumbuhan. Menurut Marassing et al. [9], teknologi fermentasi pada urin dapat menghasilkan peningkatan nilai nutrisi yang terkandung karena adanya peranan mikroorganisme 
sebagai pengurai senyawa komplek menjadi lebih sederhana. Keunggulan penggunaan urin sapi fermentasi adalah ukuran penggunaan lebih hemat, aplikasi lebih mudah karena dapat diberikan dengan penyemprotan atau penyiraman [10].

Pemanfaatan urin sebagai sumber nitrogen pupuk organik telah dimanfaatkan pada berbagai tanaman dengan umur panen yang relatif lama dengan dosis tertentu. Seperti yang dilakukan [11]. Pemanfaatan urin sebagai sumber nitrogen belum dilakukan pada tanaman dengan umur panen yang singkat seperti budidaya tanaman secara hidroponik. Atas dasar uraian tersebut maka penelitian ini dilakukan untuk mengetahui komposisi nilai nutrisi dan kecernaan nutrien secara in vitro fodder sorgum (Sorghum bicolor (L.) Moench) dari pengaruh penambahan pupuk urin terfermentasi pada media tanam hidroponik.

\section{MATERI DAN METODE}

Penelitian dilakukan pada bulan Juni September 2020, bertempat di Experimental Farm dan Laboratorium Ilmu makanan ternak, Fakultas Peternakan, Universitas Jenderal Soedirman, Purwokerto.

\section{Persiapan Bahan}

Materi tanaman yang digunakan adalah fodder sorgum (Sorgum bicolor (L) Moench) varietas numbu. Biji sorgum yang digunakan mengandung protein kasar sebesar $11,66 \%$. Pupuk urin yang digunakan berasal dari urin sapi peranakan ongole betina yang berumur 1,5 - 2 tahun. Urin sapi diperoleh dengan menampung secara langsung menggunakan ember sebelum jatuh ke lantai kandang sehingga tidak tercampur dengan kotaran. Pupuk urin terfermentasi dibuat melalui pencampuran urin sapi, kultur microorganisme dari effective microorganisms 4 (EM-4) dan tetes tebu (molasses) dengan perbandingan 20:2:1 berdasarkan [10], kemudian difermentasi selama 21 hari. Hasil analisa pupuk urin terfermentasi yang dugunakanmemiliki kadar nitrogen $(\mathrm{N})$ sebesar $1,07 \pm 0,04 \%$ serta memiliki aroma harum asam dengan $\mathrm{pH} 4,78-5,63$.
Penanaman hidroponik dilakukan menggunakan metode deep water culture system dengan pemberian media tanam melalui penyemprotan pada tanaman fodder. Perlakuan pada media tanam berupa media air tanpa pupuk urin (T1), pupuk urin terfermentasi $12,5 \mathrm{~mL} / \mathrm{L}$ (T2) dan $25,0 \mathrm{~mL} / \mathrm{L}$ media tanam (T3). Perlakuan urin sebagai penyedia unsur hara pada tanaman merupakan hasil modifikasi dari [11]. Setiap perlakuan diulang sebanyak 4 kali. Biji sorgum direndam selama 24 jam, kemudian disebar ke dalam nampan polyethylen sesuai perlakuan dengan kepadatan biji tebar sebesar $0,25 \mathrm{~g} / \mathrm{cm}^{2}$ dan ditumbuhkan selama 15 hari. Penyemprotan media tanam dilakukan sejak fodder berumur 1 hari hingga panen. Periode penyemprotan dilakukan 3 kali sehari. Hasil pemanenan fodder sorgum berupa campuran akar, batang dan daun selanjutnya dikeringkan dengan oven $60^{\circ} \mathrm{C}$ selama 48 jam, kemudian digiling dengan ukuran partikel $\pm 0.5 \mathrm{~mm}$ untuk dilanjutkan analisa komposisi nilai nutrisi dan kecernaan nutrien secara in vitro dari campuran bagian fodder tersebut.

\section{Analisa komposisi nilai nutrisi}

Komposisi nilai nutrisi meliputi bahan organik (BO), protein kasar (PK), lemak kasar (LK), serat kasar (SK), dianalisis berdasarkan metode [12]. Perhitungan bahan ekstrak tanpa nitrogen (BETN) dan total digestible nutrient (TDN) berdasarkan [13].

\section{Analisa kecernaan nutrien secara in vitro}

Uji kecernaan bahan kering (KcBK) dan kecernaan bahan organik $(\mathrm{KcBO})$, dilakukan dengan metode Tilley dan Terry [14] tahap I. Sampel dianalisa sesuai dengan perlakuan dari fodder tanaman sorgum dengan inkubasi pengujian kecernaan selama 48 jam. Sampel cairan rumen untuk uji in vitro menggunakan cairan rumen ternak domba ternak. Medium fermentasi terbuat dari campuran rumen dan larutan saliva (McDougall) dengan perbandingan cairan rumen : buffer adalah 1:4. Satu liter larutan buffer terdiri dari 9,8 gram $\mathrm{NaHCO}_{3}, 9,3$ gram $\mathrm{Na}_{2} \mathrm{HPO}_{4}$, 0,47 gram $\mathrm{NaCl}, 0,57$ gram $\mathrm{KCl}, 0,12$ gram $\mathrm{MgSO}_{4} .7 \mathrm{H}_{2} \mathrm{O}$ dan 0,0529 gram $\mathrm{CaCl}_{2} .2 \mathrm{H}_{2} \mathrm{O}$. Semua bahan tersebut dilarutkan 
ke dalam satu liter aquades. Cairan rumen dan saliva dicampur dan dimasukkan ke dalam waterbath sambil dialiri gas $\mathrm{CO}_{2}$. Kemudian campuran tersebut diambil sebanyak $50 \mathrm{ml}$ dan dimasukkan ke dalam tabung in vitro dengan volume $100 \mathrm{~mL}$ yang telah berisi sampel sebanyak $500 \mathrm{mg}$ lalu ditutup dengan karet penyumbat. Selanjutnya diinkubasi pada suhu $39^{\circ} \mathrm{C}$ dalam waterbath selama 48 jam dan digojog setiap 8 jam sekali. Blanko dibuat untuk koreksi kecernaan tetapi tidak ada penambahan sampel bahan pakan.

\section{Analisis data}

Data hasil penelitian diuji menggunakan rancangan acak lengkap pola searah kemudian untuk mengetahui perbedaan antar nilai rerata dilanjutkan uji Duncan's Multiple Range Test berdasarkan [15].

\section{HASIL}

\section{Komposisi nilai nutrisi fodder sorgum}

Pengaruh penambahan pupuk urin terfermentasi pada media tanam terhadap komposisi nilai nutrisi fodder sorgum umur 15 hari disajikan pada Tabel 1. Hasil penelitian menunjukkan perlakuan T2, dan T3 tidak berpengaruh nyata terhadap bahan kering, bahan organik, dan lemak kasar. Fodder sorgum hasil dari perlakuan penelitian ini memiliki bahan kering 16,74-17,88\%, bahan organik 95,15-95,76\% dan lemak kasar 5,17-5,68\%. Kandungan serat kasar T2 dan T3 memiliki kecenderungan menurun dibandingkan T1 (Tabel 1). Perbedaan kandungan serat kasar T2 dan T3 berturut-turut sebesar 2,96 dan 3,14\% dibandingkan $\mathrm{T} 1$.

Hasil perlakuan $\mathrm{T} 2$, dan $\mathrm{T} 3$ berpengaruh nyata $(\mathrm{P}<0,05)$ terhadap peningkatan protein kasar sebesar 6,31 dan 11,23\% dibandingkan T1 (Tabel 1). Treatmen T2 dan T3 menurunkan BETN secara nyata $(\mathrm{P}<0,05)$ dari perlakuan $\mathrm{T} 1$ sebesar $47,99 \%$ menjadi 47,34 dan $46,31 \%$. Total digestible nutrient dari T2 dan T3 mengalami peningkatan secara nyata $(\mathrm{P}<0,05)$ sebesar 2,25 dan 2,82\% dibandingkan T1.

\section{Evaluasi kecernaan nutrien fodder sorghum}

Evaluasi kecernaan bahan kering dan bahan organik fodder sorgum dari pengaruh pemberian pupuk urin terfermentasi pada media tanam hidroponik tersaji pada Tabel 2. Kecernaan bahan kering T2 dan T3 memiliki kecenderungan meningkat dibandingkan T1 (Tabel 2). Perbedaan KcBK T2 dan T3 berturutturut sebesar 3,03 dan 3,36\% dibandingkan T1. Perlakuan T3 berpengaruh nyata $(\mathrm{P}<0,05)$ terhadap peningkatan $\mathrm{KcBO}$ dibandingkan T1, cenderung lebih tinggi dibandingkan T2. Peningkatan $\mathrm{KcBO}$ berturut-turut 2,37 dan 3,06\% dibandingkan T1.

\section{PEMBAHASAN}

Bahan kering dan lemak kasar fodder sorgum dari penelitian ini tidak berpengaruh nyata dari perlakukan yang diberikan namun masih lebih tinggi dibandingkan hasil penelitian [1], pada fodder sorgum dengan varietas yang berbeda yang ditanam secara hidroponik hingga umur panen 10 hari. Disisi lain hasil penelitian [3], fodder sorgum umur

Tabel 1. Nilai nutrisi fodder sorgum umur 15 hari dari pengaruh media tanam

\begin{tabular}{|c|c|c|c|}
\hline \multirow{2}{*}{ Nilai nutrisi } & \multicolumn{3}{|c|}{ Perlakuan } \\
\hline & T1 & $\mathrm{T} 2$ & T3 \\
\hline Bahan kering $(\%)^{\text {ns }}$ & $16,74 \pm 0,89$ & $17,15 \pm 0,67$ & $17,51 \pm 0,74$ \\
\hline Bahan organik (\%)ns & $95,76 \pm 0,65$ & $95,57 \pm 0,52$ & $95,39 \pm 0,36$ \\
\hline Protein kasar (\%) & $15,22 \pm 0,12^{a}$ & $16,18 \pm 0,49^{b}$ & $16,93 \pm 0,41^{c}$ \\
\hline Serat kasar (\%) & $27,39 \pm 0,58^{b}$ & $26,58 \pm 0,74^{\mathrm{a}}$ & $26,53 \pm 0,62^{a}$ \\
\hline Lemak kasar $(\%)^{\text {ns }}$ & $5,17 \pm 0,47$ & $5,47 \pm 0,33$ & $5,63 \pm 0,48$ \\
\hline BETN (\%) & $47,99 \pm 1,08^{b}$ & $47,34 \pm 0,76^{\mathrm{ab}}$ & $46,31 \pm 0,53^{a}$ \\
\hline TDN (\%) & $60,38 \pm 0,65^{a}$ & $61,74 \pm 0,93^{\mathrm{ab}}$ & $62,08 \pm 0,99 \mathrm{~b}$ \\
\hline
\end{tabular}

$\mathrm{a}, \mathrm{b}, \mathrm{c}$ superskrip yang berbeda pada baris yang sama menunjukkan perbedaan nyata $(\mathrm{P}<0,05)$

${ }^{\text {ns }}$ superskrip menunjukan tidak berbeda nyata

T1 : Media air (kontrol internal); T2 : Urin terfermentasi 12,5 mL/L air; T3 : Urin terfermentasi 25,0 $\mathrm{mL} / \mathrm{L}$ air 
Tabel 2. Kecernaan bahan kering dan bahan organik fodder sorgum

\begin{tabular}{lccc}
\hline \multirow{2}{*}{ Kecernaan nutrien } & \multicolumn{3}{c}{ Perlakuan } \\
\cline { 2 - 4 } & $51,19 \pm 0,90$ & $\mathrm{~T} 2$ & $\mathrm{~T} 3$ \\
\hline KcBK $(\%)^{\text {ns }}$ & $51,99 \pm 0,37 \mathrm{a}$ & $52,74 \pm 1,08$ & $52,91 \pm 0,54$ \\
$\mathrm{KcBO}(\%)$ & $53,22 \pm 0,59^{\mathrm{ab}}$ & $53,58 \pm 0,72^{\mathrm{b}}$ \\
\hline a, b, c superskrip yang berbeda pada baris yang sama menunjukkan perbedaan nyata $(\mathrm{P}<0,05)$ \\
ns superskrip menunjukan tidak berbeda nyata \\
T1 : Media air (kontrol internal); T2 : Urin terfermentasi $12,5 \mathrm{~mL} / \mathrm{L}$ air; T3 : Urin terfermentasi 25,0 \\
mL/L air
\end{tabular}

panen $8,12,16$ hari menghasilkan bahan kering berturut-turut sebesar 27,04; 22,66; dan $15,68 \%$. Perbedaan komposisi nutrisi dipengaruhi oleh umur panen dan varietas fodder. Ramteke et al. [16] melaporkan bahwa hidroponik fodder memiliki banyak keuntungan diantaranya memiliki kualitas nutrien yang tinggi, mampu menghasilkan produksi dari 1-1,25 kg biji, menjadi 5,5-7,5 kg hijauan fodder, dan memiliki palatabilitas yang tinggi dari semua bagian fodder yang meliputi akar hingga daun. Menurut [17] hidroponik fodder dapat menyediakan hijauan dalam periode waktu yang cepat melalui proses germinasi yang mengandung nutrien yang berkualitas seperti protein, serat, vitamin, dan mineral. Yudhika et al. [18] menambahkan bahwa produksi BK tanaman dipengaruhi oleh ketersediaan unsur nitrogen $(\mathrm{N})$, fosfor (P) dan kalium (K) yang terkandung pada media tanam. Unsur $\mathrm{N}, \mathrm{P}$, dan $\mathrm{K}$ dibutuhkan tanaman untuk melakukan fotosintesis dan peningkatan bahan kering tanaman.

Pupuk urin terfermentasi dapat digunakan sebagai penyedia unsur $\mathrm{N}$ dan $\mathrm{P}$ pada tanaman. Menurut [19] urin ternak memiliki kandungan derivat purin. Urin ternak sapi PO Betina memiliki kandungan allantoin 37,52-47,49 mmol/ekor/hari dan uric acid 4,15-4,93 mmol/ekor/hari. Allantoin merupakan komponen terbanyak dalam derivate purin selanjutnya komponen uric acid. Hafez et al. [20] menambahkan derivat purin terdiri atas hypoxanthine, xanthine, uric acid, dan allantoin, dengan allantoin merupakan proporsi terbanyak dalam katabolisme purin. Uric acid dan allantoin dapat dimanfaatkan sebagai sumber nitrogen yang digunakan untuk pertumbuhan pada tanaman.

Penambahan urin terfermentasi sebanyak $12,5 \mathrm{~mL} / \mathrm{L}$ dan $25,0 \mathrm{~mL} / \mathrm{L}$ air memberikan pengaruh terhadap peningkatan protein kasar dibanding kontrol. Nilai protein yang dihasilkan sebanding dengan [3]. Menurut [21] ketersediaan unsur $\mathrm{N}$ pada media tanam berkorelasi dengan pembentukan protein pada tanaman. Ion $\mathrm{N}$ diserap oleh akar kemudian diubah menjadi $\mathrm{NH}_{2}$. Jaringan akar menyerap N-nitrat dan mereduksinya menjadi amonium dengan enzim yang mengandung molibdenum. Ion amonium atau bentuk lainnya dan karbohidrat yang disintesis daun akan diubah menjadi asam-asam amino pada bagian tanaman seperti akar, batang dan daun. Menurut [16] media dan nutrien diperlukan untuk proses germinasi dan pertumbuhan. Konversi unsur hara dari media dan cadangan makanan dalam biji digunakan untuk metabolisme penyusunan komponen kandungan nutrien tanaman. Germinasi akan menghasilkan pertunasan dan perakaran primer yang dapat dikonsumsi oleh ternak. Sodiq et al. [22] menambahkan bahwa urin mengandung fitohormon alami berupa auksin, giberelin dan sitokinin. Auksin berfungsi untuk percepatan proses germinasi, pertumbuhan akar dan batang. Giberelin berfungsi dalam mengatur proses germinasi, perkembangan meristem sekunder. Sitokinin berfungsi dalam perkembangan jaringan meristem, pertumbuhan dan diferensiasi sel pada proses germinasi.

Pemberian urin terfermentasi sebagai sumber nitrogen dalam media, menjadikan salah satu faktor terjadinya peningkatan pertumbuhan fodder sorgum. Hal ini sebanding dengan [23] bahwa penambahan larutan urin kambing sebagai media penyiraman dapat meningkatkan perkecambahan sebanyak 5,19\% dibandingkan tanpa penambahan urin. Leghari et al. [24] menyatakan bahwa nitrogen 
merupakan komponen esensial yang berperanan dalam aktivasi enzim selama proses germinasi, metabolisme protein, meningkatkan proses fotosintesis dan biomasa tanaman.

Penurunan serat kasar dimungkinkan dari ketersediaan nitrogen dalam media tanam fodder sorgum. Biji sorgum yang digunakan dalam penelitian mengandung protein kasar sebesar $11,66 \%$. Penambahan urin terfermentasi berpengaruh terhadap komposisi serat kasar dibandingkan tanpa perlakuan. Serat kasar yang dihasilkan lebih rendah dibanding fodder sorghum dengan umur tanam 12 dan 16 hari oleh [3, 7]. Peningkatan serat kasar terjadi karena sintesis dan penebalan dinding sel sekunder sehingga laju pematangan dan pengairan berpengaruh terhadap penumpukan lignin. Selanjutnya kandungan serat sebagian besar berasal dari akar dan epidermis biji akibat proses pematangan dan endosperm [17]. Kadar serat kasar bertambah seiring dengan umur tanaman karena bertambahnya komponen dinding sel tanaman. Penurunan serat kasar diikuti penurunan kadar BETN sebesar 1,36-3,50\% dibandingkan T1. Menurut [25] kadar BETN dipengaruhi oleh kandungan protein, semakin tinggi kadar protein akan menurunkan kadar BETN karena kadar nitrogen yang ada seluruhnya terhitung sebagai protein kasar.

Fodder sorgum dalam penelitian ini memiliki TDN yang lebih tinggi dibandingkan sorgum [26] dengan TDN sebesar 48,9-59,0\%. Hal ini sebanding dengan [20] tanaman fodder serealia memiliki kandungan TDN $64,00 \%$ dan protein kasar 12,48\%. Menurut [27] TDN merupakan sistem asupan energi pada pemberian pakan ternak ruminansia. Peningkatan TDN berkorelasi positif terhadap kadar protein kasar, namun berkorelasi negatif terhadap peningkatan kadar serat kasar. Ketersediaan nitrogen dalam pakan berdampak terhadap perkembangan mikrobia rumen sehingga kecernaan pakan menjadi lebih tinggi.

Hasil KcBK penelitian ini lebih rendah dibanding dengan [16], fodder jagung dengan umur panen 8-10 hari menghasilkan KcBK sebesar $61,15 \%$ dan KcBO 64,20\%. Perbedaan kecernaan nutrien dapat disebabkan oleh jenis fodder, umur panen, dan metode dalam melakukan analisa kecernaan secara in vitro. Kecernaan bahan kering penelitian ini lebih tinggi daripada Sorghum plumosum var [7] sebesar 40,2-50,0\%. Menurut [28] menyatakan semakin tinggi kecernaan bahan kering suatu bahan pakan sebanding dengan kualitas bahan pakan tersebut. Kecernaan bahan organik lebih tinggi dibandingkan nilai kecernaan bahan kering dari suatu bahan pakan.

Penambahan urin terfermentasi sebagai sumber $\mathrm{N}$ dalam media tanam mampu meningkatkan $\mathrm{KcBO}$ dibandingkan kontrol. Hasil penelitian $\mathrm{KcBO}$ fodder sorgum ini sebanding dengan [29] sebesar 47,96-53,85\%, namun lebih rendah dari [1] sebesar 80,02-81,59\%. Peningkatan $\mathrm{KcBO}$ sebanding dengan meningkatnya protein kasar dan menurunnya kandungan serat kasar sebagai komponen organik. Menurut [30], bahan organik dalam suatu pakan yang mudah dicerna berasal dari BO yang mudah larut seperti protein, karbohidrat terlarut dan lemak. Meningkatnya SK menyebabkan menurunnya nilai degradasi karena SK memiliki komponen selulosa dan hemiselulosa yang sering berikatan dengan lignin sehingga sulit dipecah oleh enzim pencernaan.

\section{KESIMPULAN}

Penambahan pupuk urin terfermentasi pada media tanam sebanyak 25,0 mL/L mampu meningkatkan komposisi protein kasar dan kecernaan bahan organik fodder sorgum pada umur panen 15 hari.

\section{KONFLIK KEPENTINGAN}

Penyandang dana tidak memiliki peran dalam desain penelitian; dalam pengumpulan, analisis, atau interpretasi data; dalam penulisan naskah, atau dalam keputusan untuk menerbitkan hasilnya.

\section{UCAPAN TERIMA KASIH}

Terimakasih kepada LPPM Universitas Jenderal Soedirman yang telah memberikan pendanaan kegiatan penelitian melalui 
program hibah skema riset dosen pemula SK Kept.122/UN23.18/PT.01.05/2020.

\section{DAFTAR PUSTAKA}

1. Wahyono, T., H. Khotimah, W. Kurniawan, D. Ansori, dan A. Muawanah. 2019. Karakteristik tanaman sorghum green fodder (SGF) hasil penanaman secara hidroponik yang dipanen pada umur yang berbeda. Jurnal Ilmu dan Teknologi Peternakan Tropis. 6(2):166-174. Doi: 10.33772/jitro. v6i2.5722

2. Sharma, N., S. Acharya, K. Kumar, N. Singh, and O. P. Chaurasia. 2018. Hydroponics as an advanced technique for vegetable production: an overview. J. Soil. Water Conserv. 17(4):463-371. Doi: 10.5958/2455-7145.2018.00056.5

3. Chrisdiana, R. 2018. Quality and quantity of sorghum hydroponic fodder from different varieties and harvest time. Proc. IOP Conf. Ser. Earth Environ. Sci. Doi: 10.1088/1755-1315/119/1/012014

4. Nikolas, N., A. Rusae, dan B. Atini. 2017. Identifikasi hama dan aplikasi bioinsektisida pada belalang kembara (Locusta migratoria, 1) sebagai model pengendalian hama terpadu pada tanaman sorghum. Jurnal Pertanian Konservasi Lahan Kering. 2(3):46-47.

5. Kumalasari, N. R., A. T. Permana, R. Silvia, dan A. Martina. 2017. Interaction of fertilizer, light intensity and media on maize growth in semi-hydroponic system for Feed production. Proc. 7th ed. Int. Semin. Trop Anim. Prod. Yogyakarta.

6. Koten, B. B., R. D. Soetrisno, N. Ngaadiyono, dan B. Soewignyo. 2012. Produksi tanaman sorghum (Sorghum bicolor (L.) Moench) varietas lokal rote sebagai hijauan pakan ruminansia pada umur panen dan dosis pupuk urea yang berbeda. Buletin Peternakan. 36(3):150-155.

7. Keraf, F. K., Y. Nulik, dan M. L. Mullik. 2015. Pengaruh pemupukan nitrogen dan umur tanaman terhadap produksi dan kualitas rumput kume (Sorghum plumosum var timorense). Jurnal Peternakan Indonesia. 17(2):123-130. Doi: 10.25077/jpi.17.2.123-130.2015
8. Mudhita, I. K., N. Umami, S. P. S. Budhi, and E. Baliarti. 2016. Effect of bali cattle on legume cover crop puero (Pueraria javanica) productivity on east borneo oil palm plantation. Pak. J. Nutr. 15(5):406-411.

9. Marassing, J. S., W. B. Kaunang, F. Dompas, dan N. Bawole. 2013. Produksi dan kualitas rumput gajah dwarf (Pennisetum purpureum cv Mott) yang diberi pupuk organik hasil fermentasi EM4. J. Zootek. 32(5):158-171. Doi: 1035792/ zpt.32.5.2013.990

10. Huda, M., Latifah, dan A. T. Prasetya. 2013. Pembuatan pupuk organik cair dari urin sapi dengan aditif tetes tebu (molasses) metode fermentasi. Indones. J. Chem. Sci. 2(1):1-13.

11. Lestari, S. U. dan A. Andrian. 2017. Effects of urin cow dosage on growth and production of sorgum plant (Sorgum bicolor L) on peat land. Proc. IOP Conf. Ser. Earth Environ. Sci. Doi: 10.1088/1755-1315/97/ $1 / 012052$

12. AOAC. 2005. Official method of analysis. 18th ed. Assoc. Off. Anal. Chem., Maryland William Harwitz (ed), United States of America.

13. Hartadi, H., S. Reksohardiprojo, dan A. D. Tillman. 2005. Tabel komposisi pakan untuk Indonesia. Cetakan kelima. Gajah Mada University Press, Yogyakarta.

14. Tilley, J. M. A. and R. A. Terry. 1963. A two stage technique for in vitro digestion of forage crops. J. br. Grassl. Soc. 18:104-111.

15. Gomez, K. A. and A. A. Gomez. 1984. Statistical procedures for agricultural research. 2nd ed. A Willey Interscience Publication, New York.

16. Ramteke, R., R. Doneria, and M.K. Gendley. 2019. Hydroponic techniques for fodder production. Acta. Sci. Nutr. Health. 3(5):127-132.

17. Al-Karaki, G. N. and M. Al-Hashimi. 2012. Green fodder production and water efficiency of some forage crops under hydroponic conditions. ISRN Agron. 5:1-5. Doi: $10.5402 / 2012 / 924672$

18. Yudhika, F.A., A. Hanifa, dan E. Handayana. 2017. Efektifitas produksi nutrien tanaman sorgum dan jagung bagian aerial dengan media tanam yang 
berbeda. Jurnal Sains Peternakan. 15(2):7886. Doi: 10.20961/sainspet.v15i2.14334

19. Suprayogi, W. P. S. 2003. Sintesis protein mikrobia sapi peranakan ongole yang diberi pakan berserat. J. Indones. Trop. Anim. Agric. 28(3):115-118.

20. Hafez, R. M., T. M. Abdel-Rahman, and R. M. Naguib. 2017. Uric acid in plant and microorganisms: biological applications and genetics - a review. J. Adv. Res. 8(1):475-486. Doi: 10.1016/j.jare.2017.05.003

21. Muratore, C., L. Espen, and B. Prinsi. 2021. Nitrogen uptake in plants: the plasma membran root transport systems from a physiological and proteomic perspective. Plants. 10(1):681-706. Doi: 10.3390/plants 10040681

22. Sodiq, A. H., M. R. Setiawati, D. A. Santosa, and D. Widayat. 2019. The potency of bio-organic fertilizer containing local microorganism of cibodas village, lembang-west java. Proc. IOP Conf. Ser. 1st ed. Intern. Conf. Agric. Rural Dev. Doi: 10.1088/1755-1315/383/1/012011

23. Kustyorini, T. I. W., A. T. N. Krisnaningsih, dan W. B. Ria. 2019. Pengaruh konsentrasi larutan urin kambing sebagai media penyiraman dan pupuk organik terhadap presentase perkecambahan, persentase kecambah normal dan produksi hijauan segar pada fodder jagung (Zea mays) dengan sistem hidroponik. Jurnal Sains Peternakan. 7(2):135-140. Doi: 10.21067/jsp. v7i2.4009

24. Leghari, S. J., N. A. Wahocho, G. M. Laghari, A. H. Laghari, G. M. Bhabhan, K. H. Talpur, T. A. Bhutto, S. A. Wahocho, and A. A. Lashari. 2016. Role of nitrogen for plant growth and development: a review. Adv. Environ. Biol. 10(9):209-218.

25. Fitriana P. R., Hidayat, dan T. Akbarillah. 2017. Kualitas Nilai Rumput setaria yang dipanen berdasarkan interval pemotongan. Jurnal Sain Peternakan Indonesia. 12(4):444-453. Doi: 10.31186/jspi. id.12.4.444-453

26. Singh, S., B. V. Bhat, G. P. Shukla, K. K. Singh, and D. Gehrana. 2018. Variation in carbohydrate and protein fraction, energy, digestibility and mineral concentrations in stover of sorghum cultivar. Trop. GrasslForajess. 6:42-52. Doi: 10.17138/tgft(6)42-52

27. Indah A. S., I. G. Permana, dan Despal. 2019. Model pendugaan total digestible nutrient (tdn) pada hijauan pakan tropis menggunakan komposisi nutrien. Jurnal Sains Peternakan. 18(1):38-43. Doi: 10.20961/sainspet.v\%vi\%i.35684

28. Sondakh, E. H. B., M. R. Waani., J. A. D. Kalele, dan S. C. Rimbing. 2018. Evaluation of dry matter digestibility and organic matter of in vitro unsaturated fatty acid based ration of ruminant. International. J. Current. adv. Res. 7(6):13582-12584. Doi: 10.24327/ijcar.2018.13584.2434

29. Puteri, R. E., P. D. M. H. Karti, L. Abdullah, dan Supriyanto. 2015. Productivity and nutrient quality of some sorghum mutant lines at different cutting ages. Media Peternakan. 38(2):132-137. Doi: 10.5398/ medpet.2015.38.132

30. Tillman, A. D., H. Hartadi, S. Prawirokusumo, S. Reksohadiprojo, dan S. Lebdosoekojo. 1998. Ilmu makanan ternak dasar, cetakan ke-6. Gadjah Mada University Press, Yogyakarta. 